資料

\title{
車室内照度に関する研究報告 (概要)
}

これは昭和33年度国鉄技術関係部外委託研究の一項目 こして社団法人車雨電気協会に委託された「車室内照度 亿関する研究」の報告である。協会に批いては昭和33年 8 月準備会を開き，「車室内照度に関する研究委員会」

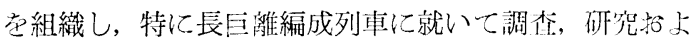
び試験を行い, 慎重番議つ結果, 本年 3 月, この報告書 を作成し, 提出した。委員中, 当学会関䋆者は次の諸氏 である. 委員長 黑沢凉之助, 翰事 正木 光, 河原鶴 松, 藤原義輝, 委員 内田重窟, 小原滈成, 鈴木繁好,

星 隼人, 高須孔武

内容は

(1)緒言，(2)研究方剑，(3)研究項目，(4)研究の経過，

(5)基礎調查，(6)長巨離列車の照明の現状，(7)長巨離列 車の照明のありかた，(8)結言

であり，本交19頁，附録30頁より成っている.

本報告のうちこの年度に招いて採上げられた研究事項 たる長旦髉列車の照明に関し, その概要势記すと次の通 りである。

\section{長距離列車の照明の現状}

現在の長巨離急行扣よで特別急行列車は「あさがせ 「こだま」を除いては, 普通の客車, 電車に見られる一 般の照明設備をもっている. 電源は車軸発電機, 䈉電池 により, 白熱電球の場合は直流で, けい光灯の場合には インバータによる交流点灯が普通である.

電灯設備は白熱電球によるものも相当あり, 大低は 40 W電球㣙ローブを用いている. けい光灯は白色 $20 \mathrm{~W}$ 大部分で, 裸取付け又は乳白色グローブ付きもあるが連 続列になっている.

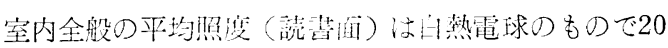
〜 60 1x, けい光灯のもので60〜150 lx である. 又食堂車 は比較的新らしい車雨で食卓面で約 $150 \mathrm{~lx}$ である。

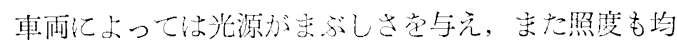
㖖でないものが少くない。これらは一般に車室内が生地 梁仕上の反射率の低いものが多いため照明効果血くし ている.

このような一般長巨離列車化対して「あさか就」は編 成列車として製作され，電源車索連結し三相父流で各東 両に送電しているので，照明用電源は充分であり，電 正，周波数の变動も非常化少ない，A，Bの2 編成为作 られたが座席車はいずれも両側座席直上に40W 1 灯用合

$\dagger$ The Report of Illumination with Railway Passenger Car Lighting.
成樹脂カバー付器具が連続に配置されて招り, 空内全般 の平均梁废は 2 等車で $\mathrm{A}$ 編成 $220 \mathrm{~lx}, \mathrm{~B}$ 編成 $340 \mathrm{~lx}, 3$ 筞車で $\mathrm{A}$ 編成 250 1x，B編成 $305 \mathrm{~lx}$ である. A 編成の空

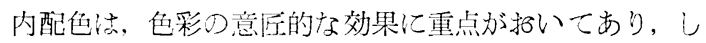
たがってけい光灯も天然白色を用いているが，B編成で は内部空反射率の高い色に仕上げ，白色けい光灯を用い

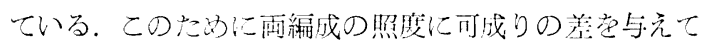
いる.

「あさかぜ」の，対照として「はやぶさ」とについて 行われた乗客の意見調查結果に上机谋，「あさかぜ」の

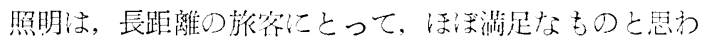
れる。

「こばま」「あさかぜ」の坐席車と同じく40Wけい 光灯合成樹脂カバー付器具が座庥直上に漊続列になって いるが室内の仕上が異るのと, 天井が低いた的に照度於 高く400〜 $5001 \mathrm{x}$ を示している.

\section{長距離列車の照明のありかた}

之は本報告の主文であり 3 節に分かれている。

\section{（1）照明に関する基本の考え方}

先づ照度については一般室内に招けると同一の作業打 よご場所に対して, 車雨の振動, その他の環境走考虑し 一般室内汇打惟奖照度の約 2 倍党必要とする。車雨 のように天井の低い所では，まぶしさをのぞくために白 熱電球は必ずグローブ等で㠅い，けい光灯もなるべくカ バーをかける事が望ましく, 又室内はなるべく高い反射

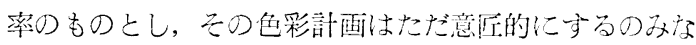
らず，機能的の面加らも考えるべきである。

\section{(2) 照明の手段}

車両照明に抽いては限りある電源を利用するるので，効 率の高い点からけい光灯が遌ばれる。色は天然白色が望 ましいが, 使用場所によっては設销し得る灯数, 室内照 度值加見て，効率がよく，光束減湜の少小白色を使用 してもよい.

照明器县法長胿問眼にふれるものであるから, 装飾が すざたり，奇抜すぎるものはかえって不快となる，機能 本代の自然な外観で，さっぱりしたものが望ましい，又 天井永低く, 狭いから压迫感在さけるために器具の天井 からの出っ張り極力少なくする。

電源はなるべく別に電源車を連結し，乙れに荅載され た発電機による $100 \mathrm{v}$ 双は $200 \mathrm{v} の$ 交流が望ましく, 客車 1 車両当りの照明用電力は $1.5 \sim 2 \mathrm{~kW}$ 在要とする. 電 源車から各車両えの配電は $200 \mathrm{v}$ 以上の電圧で, 各車両 
亿変圧器を設置して使用電圧に下げる方式が望ましい，

\section{(3) 車室照明各論}

(1) 座席車の客席

座席車で普通行われる作業は読書，執符，編物等で， これらに推奖される照度は通例 $2001 \mathrm{x}$ 程度であるが車雨 つ場合は振動堂考慮して，これ起迴るものが要求点れ 万.

近来けい光灯 1 灯用合成樹脂カバー付器具を天井長手 方们に沿って, 雨側座席上に連続一列ずつ配置する方法 がよく行われている，との場合 300４00 lx の照度が読 書而に汴一様に得られる。

けい光灯の連絩列を天井中心線上汇一列だけ取付计， 荷物棚下の座席灯（電球党用いたダウンライト式）を用 いて局部的に照度孛補うのも岁圮一つの方法であるが， 車室内全般的の照明状態は前者の方法に劣る.

捙続列 2 列の前者の場合にも來席灯を併用する事があ る. 座席灯は減光時にも個人の読書が許され，乙れを旅 客めいめいの選択にまかせる利点がある。

旅客の就眠時には睡眠を妨げ奴ため照度を低下させ る.睡眠のためには暗いほどよいが,保安上或は夜中乗降 または手洗等の乙とを考㥿すれぼ $301 x$ 前後はほしい. 減 汅させる方法として,ランプの間引き点灯と, 全体を調光 器で減光させる方法とがある。後者は照度分布变えず に睦くし得る利点があり, 前者は暗い灯具と元のままに 輝く灯具とが同時に眼に入って不快を伴う久点がある。

(a) 嗙台車

之を㭫席として使う場合には前の(份の場合に準ずる。

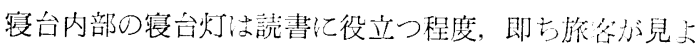
うとする書物の面に少くとも $50 \mathrm{~lx}$ を与光，海の力问は

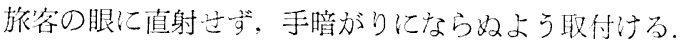
又カーテンは通路の天井灯，床灯等の光がもれないるう にする必要がある，葠台老作った時の通路はやなり $30 \mathrm{~lx}$ 前後とし, 天井灯の調光と，床灯によって与党方

(v) 食堂車

一般の食堂にならえばよく, 照度はさ活ど大きいこと 在必要としないが，他の車両との釣合上 300 400 lx 程 度とする，料理室には特に天然白色けい光灯の使用が望 ましい。

$\Leftrightarrow$ 化籸室, 舆煙室, 便所

全光時 $100 \mathrm{~lx}$, 減光時も $30 \mathrm{~lx}$ 程度が望ましい。乙れ らの照度は器物のあたりにほぼ一様に分布させる。化粧 空のけい光灯は天然白色を用いる。化粧室抢上ご喍䙳窒 は減光時に衫いても, 必要に応じて明るく出来るように する。

(木) 出入台

列車全体として各客室廊下の照度ならびにプラットホ 一ムの照度との関連を考光て床面に沏いて $30 \mathrm{~lx}$ 程度が 望ましい，光源は電球でもけい炏灯でもよいか，出来れ 济天井灯に床灯䘮加气る。

本報告の絬言に扔いては，長巨離編成列車では車内で の人の往来考考罳し, 全列車各部の照度, 光色等が編成

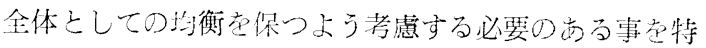
郭した。

(藤 原 義 輝)

\section{資料}

\section{照明エ学の邦書について}

照明教育委員会準䚚小委員会

先に本会誌筑 43 姿筇 3 耍 (1959) に照明工学の邦 書のリストを紹介したが，本突員会焚員，関重広氏より その禣充と追加を申出られたので次に紹介する。

\section{A 変遷史, 写真帳等}

$$
\text { 火と日本海野三郎山满觉 (昭16年) }
$$

\section{B 一般的な電灯照明ならびに理論設計計算等} 電灯及照明 電気教育研究会 コロナ社（昭 6 年） 電灯電熱電父店用電気学会 電父書院 (昭24年) 理緰にもとづく照明の実際

関 重宏 電機大学 (昭33年)

\section{C 特殊な照明, 光源, ならびに視覚等}

電気サイン及看板照明 内坂素夫 三省堂 (昭 4 年) 水産と電気電気協会昭18年)
家庭の電化関 重広 彭考曹院 (昭22年) 商店照明とディスプレイ 柳濑㥍 暗国社 (昭32年)

\section{E 色彩に関するもの}

商業と色彩

芸術と色彩

大智 浩 修道社

富永怱一 "

服飾美容之色彩 田中干代・細野晌志” 色彩の心理西川好夫法大出版部 私たちの生活と配色雇藤亘厷满談社 生活と色彩 色彩綸 配色就本 色 勝見 勝 河出書房 稻村耕雄岩波書店 細野向志修道社 東堯 河出書房 